\title{
PRESENTACIÓN
}

\section{REFLEXIONES A LA INTEMPERIE}

"La ciudad está en cuarentena

La ciudad apesta. La ciudad es insalubre. La ciudad está aislada. Se aisla a los enfermos contagiosos. El contagio de la peste es muy rápido. La peste es una epidemia desoladora.

Reina una epidemia". (La ciudad, Gonzalo Millán, 1979)

La pandemia mundial por Covid-19, que tuvo sus inicios en Chile a mediados de marzo de 2020, ha generado una crisis sanitaria con serias consecuencias en lo social y en lo político, que ha ido horadando un sistema ya cuestionado en el estallido social de octubre de 2019.

En este contexto, las demandas por dignidad y justicia social que otrora se tomaron las calles volvían a adquirir sentido y reafirmaban la crisis de un Estado superado por las circunstancias sanitarias, con un impacto fatal que al cierre de esta edición cobraba la vida de más de 17.000 mil personas.

Así, día tras día, el virus del Covid-19 ha develado de forma brutal lo que ya se advertía. Que el impacto de la enfermedad no sería democrático porque la enorme desigualdad que el modelo neoliberal había instalado en Chile agudizaría todavía más la pobreza, el hacinamiento y la precariedad del trabajo informal de millones de personas.

En medio de esta realidad confinada, que todavía enfrentamos con dudas e incertidumbre, y en el espíritu que ha caracterizado históricamente a la Revista Anales de la Universidad de Chile, nos dimos a la tarea de pensar un número en el cual dialogaran diversas voces a partir de una triada esencial para pensar la catástrofe: pandemia, Estado y crisis social. Para ello, convocamos a artistas, intelectuales, académicas y académicos, feministas, científicos, representantes institucionales, periodistas, historiadoras, historiadores, filósofos, quienes, a partir de sus campos 
de conocimiento y a través de sus reflexiones y preguntas sobre temáticas como salud, trabajo, educación, arte, archivos, políticas públicas, derechos humanos, datos, entre otros, dieran forma a un volumen que, sabemos, será testimonio esencial de la pandemia cuando sea el tiempo de evaluar.

No es tarea fácil pensar al calor de la crisis, pero es un ejercicio que tras cinco meses nos parece fundamental, pues tal como vemos en el dossier histórico de este número, el rol de nuestra Casa de Estudios ha sido central en la construcción de políticas públicas que permitan al Estado responder en contextos de crisis sanitaria.

A los artículos desarrollados por relevantes voces del pensamiento crítico nacional sumamos en esta oportunidad un dossier de creación que da cuenta de las reflexiones literarias que Pía Barros, Rosabetty Muñoz, Kemy Oyarzún, Naín Nómez, Maribel Mora Curriao e Ivonne Coñuecar han hecho durante los meses del confinamiento y que da testimonio de las posibilidades que entrega el lenguaje poético para enunciar aquellas experiencias límite propias de la catástrofe.

Asimismo, incluimos una entrevista realizada por la Doctora en Psicología y directora de Extensión de la Vicerrectoría de Extensión y Comunicaciones, Svenska Arensburg, al prominente psicoanalista y académico de la Universidad Nacional de Lanús, Argentina, Emiliano Galende, quien aborda extensamente los desafíos de la salud mental comunitaria y la respuesta pública a la emergencia.

El ya tradicional dossier histórico, a cargo de la directora del Archivo Central Andrés Bello, Alejandra Araya, complementa los textos de este número a partir de documentos, tesis de investigación, informes, literatura de cordel, reportajes y fotografías que contienen parte de la historia de la salud, enfermedades y asedios virales experimentadas en nuestro país, los que, al menos en el pasado, significaron avances fundamentales e integrales en materia de políticas públicas de salud.

Mención aparte merece el texto del rector de la Universidad de Chile, Dr. Ennio Vivaldi, quién aborda el rol de la universidad pública en un contexto de crisis, y exhibe el amplio e insustituible aporte no solo de la comunidad científica de nuestra universidad, sino de todos los ámbitos y disciplinas, ratificando el compromiso público de la principal Casa de Estudios superiores de Chile con el destino de su país.

Cierra este número la transcripción del diálogo "Estado, pandemia y transparencia", realizado el 9 de julio a través de la vía telemática, que trató una de las grandes discusiones en torno a cómo el Estado ha abordado la crisis: la importancia del acceso, la información y la transparencia de las cifras y datos que permiten no solo dimensionar los efectos de la pandemia y definir acciones concretas, sino también salvar vidas. A la luz de estas discusiones, conversaron con la editora de Anales, Jennifer Abate, Ennio Vivaldi, rector de la Universidad de Chile; Izkia Siches, presidenta del Colegio Médico de Chile; Eduardo Engel, 
Profesor Titular de la Universidad de Chile y director del centro de estudios Espacio Público; y Mary Kalin, Profesora Titular de la Universidad de Chile, directora del Instituto Milenio de Ecología y Biodiversidad de la Universidad de Chile y Premio Nacional de Ciencias Naturales 2010.

Cuando las nuevas generaciones quieran saber qué pasó en nuestro país durante la pandemia, cuáles fueron los debates que la cruzaron, cómo se enfrentó la crisis, cómo se vivió desde el mundo del arte y la creación o qué rol tuvo en dicha crisis la Universidad de Chile, tenemos la convicción de que este número de la Revista Anales será un aporte fundamental.

Faride Zerán Chelech

Vicerrectora de Extensión y Comunicaciones Directora de la Revista Anales de la Universidad de Chile. 